\title{
Sraffa and the Marshallian tradition*
}

\author{
Annalisa Rosselli
}

\section{Introduction}

'In the circumstances, I think it is Marshall's theory that should be discarded' (Sraffa 1930: 93). With these words Piero Sraffa concluded his contribution to the Symposium on Increasing Returns and the Representative Firm published in March 1930 by the Economic Journal-a contribution defined by Keynes in the introduction as 'negative and destructive'. And indeed the effects of Sraffa's attack on Marshallian orthodoxy left deep marks on the economists of a Cambridge where, until shortly before, the doctrine had been that: 'It is all in Marshall', and where Keynes liked to repeat that all one needed to be a good economist was a thorough knowledge of the Principles and careful daily reading of The Times (Harrod 1951: 324).

As Austin Robinson recalled in one of his many memoirs, the Symposium, with Sraffa's sharp call to abandon Marshallian theory, marked the end of a process that had begun with Sraffa's 'painful hesitation' (Robinson 1990: 3) about revealing a few cracks in Marshallian orthodoxy. At the same time it marked the opening of a profound divergence between the new and old generations of Cambridge economists on the issue of allegiance to Marshall. The Marshallian old guard, represented in the Symposium by Dennis Robertson and Gerald Shove, emerged from the clash confused and disconcerted: while unwilling to repudiate Marshall, they could not produce adequate counter-arguments on the ground where Sraffa centred his attack - that of logical consistency and the empirical relevance of static analysis. Nor could they shift their defence to another plane - that of the richness of Marshall's approach even if it did not lend itself to representation in graphs or formulas. The younger generation to which

\section{Address for correspondence}

Dipartimento Economia e Istituzioni, Facoltà di economia, Via Columbia 2, 00133

Roma, Italy; e-mail: annalisa.rosselli@uniroma2.it

The European Journal of the History of Economic Thought 
Austin Robinson himself belonged, together with his wife, Joan, and Richard Kahn, felt free to explore alternative paths, and just a few months later all three launched the first of the Cambridge 'revolutions' of the 1930s - the theory of imperfect competition - fuelling that 'orgy of analytic geometry' (to use the happy expression coined by Becattini 1986: 51), which Pigou had begun, and which was to keep all of them busy for several years.

While there can be no doubt about the role Sraffa played in fostering reappraisal of Marshallian theory, albeit with probably not quite the results he would have liked, it is far less easy to follow the individual line taken by Sraffa that led him to the drastic conclusions of the Symposium. His sharp, trenchant tone here seems a long way from the cautious attitude he took in his previous article of 1926 in the same journal, where, although subjected to keen criticism, Marshall received scant explicit mention, and that was mostly with reference to definitions that Sraffa cited approvingly. Are we to take the change in tone as a sign that he was shedding a degree of caution that had been necessary for a young and unknown Italian economist writing for a journal published in the stronghold of Marshallian tradition? Or does it not rather show that Sraffa had come to acknowledge the impossibility of correcting a theory that he had originally viewed as a fruitful basis for further developments?

This article aims to answer these questions, retracing some of the stages in Sraffa's thinking about the work of Marshall. I shall endeavour to demonstrate that Sraffa's criticism of Marshall unfolded along with his efforts to determine the requisites for the theory of prices he had in view. Thus we have two parallel paths-a path of destruction and a path of construction-which evidently influenced each other while retaining a certain autonomy. In fact, subsequent to the 1926 article-which showed the inability of Marshall's theory to explain variations in costs by changes in output-we find no evidence of Sraffa putting his finger on successive weak points, which might have marked a progressive abandonment of Marshallian theory leading to the final break. At the same time, however, his criticism of Marshall continued even after Sraffa had taken a more satisfactory line of research with the formulation, in November 1927, of the 'first equations' that would evolve into Production of Commodities by means of Commodities. In this respect, the Symposium does not mark Sraffa's recognition of the impossibility of correcting a theory or method-which he had never embraced-but rather abandonment of a tactic in attacking marginalist theory, which we might define as the 'quest for the fatal error', or, in other words, finding flaws in the logical construction of Marshallian theory, and thereby setting about the demolition of the entire edifice. 
I shall therefore try to demonstrate that Sraffa never endorsed the unifying principle, method and, above all, conclusions about the theory of distribution, of the Marshallian framework. He did not accept the unifying principle of representing economic phenomena as the outcome of a 'balancing of divergent motives in the minds of men', as Shove (1942: 306) was later to define it. Nor did he subscribe to the method of marginal magnitudes, which are not observable magnitudes but are the result of mind experiments conducted by the economist. Nor did he approve of the correspondence drawn between labour and capital, both being recompensed according to the same law of incentive to individual sacrifice. Sraffa appears as a convinced anti-Marshallian from the outset, and his dissent, which we may call pre-analytic, found expression in criticism that took various forms. It acquired increasingly solid logical grounds, but essentially reiterated the same charge touching upon the very foundations of the Marshallian framework: Marshall had sought to draw together the absolutely irreconcilable (Ricardo and Jevons, cost and utility) while keeping separate in 'watertight compartments' 1 what cannot be separated: determination of price and distribution. My account will draw amply on the papers in the Sraffa archive relating to the publication of the 1925 and 1926 articles and his contribution to the Symposium, as well as the extant papers regarding Sraffa's activity before 1928, or in other words preceding or accompanying the development of the 'first equations' of Production of Commodities by Means of Commodities in November 1927. A large proportion of this latter set of papers (D1/1-51) was rearranged by Sraffa himself, who collected them in files bearing indication of the various subjects. With a few exceptions they are undated, and Sraffa's subsequent rearrangement makes it hard to track down the one clue-the fact of belonging to the same writing book or notebook - that might have suggested the order in which they were drawn up. On top of the usual difficulties we have in interpreting Sraffa's manuscripts-for example, to understand whether he copied certain passages from authors with approval or disapproval-we also have the uncertainty over their chronological order. On the basis of these papers, therefore, it is practically impossible to achieve any incontrovertible reconstruction of the evolution of Sraffa's ideas over time. Their value to us here lies in the fact that they also tell a story of endeavours and failures, of paths taken only to be abandoned. As Sraffa himself once said, near the end of his life: 'In economic theory the conclusions are sometimes less interesting than the route by which they are reached! ${ }^{2}$ Thus, in the conviction that some questions may prove as interesting as answers, I believe these papers have an important part to play in the overall reconstruction of Sraffa's thought. 


\section{The 1923 writing-book}

The influences that may have been in play in Sraffa's first reading of Marshall's work have been examined by various authors. Attention has been drawn to the Marshallian background to the environment where Sraffa received his university education in Turin (Faucci 1986), and more generally to the importance Marshall held in the Italian economic thought of the period (Gallegati 1984); it has also been conjectured that Pantaleoni exerted a certain influence (Opocher 2003). Others have dwelt on the significant contribution to Sraffa's educational background of the months spent in 1921-2 at the London School of Economics (LSE), where the leading light was Edwin Cannan, whose lessons Sraffa appears to have followed with great 'interest and assiduity' (Pasinetti 1985: 319). According to recollections in the autobiography of Lionel Robbins, who was attending the LSE in exactly the same period, Cannan would often assume a denigratory tone in his lectures to stress this or that weakness in the thought of 'old Marshall', as he called him (Robbins 1971: 85). However, Sraffa clearly had a low opinion of Cannan's interpretation of the Classical economists-in a note penned in 1923 he describes him as a 'false interpreter' (D1/2.2) - and we have no reason to believe that he thought much better of his interpretation of Marshall. Probably Cannan's influence went no further than the precept not to speak of the Principles without having compared the various editions-a habit that Cannan cultivated (Robbins 1971: 86) and that Sraffa would never abandon.

Cannan's course was held without textbooks or reading list, and thus we cannot tell exactly what Sraffa was reading at the time ${ }^{3}$. What we do know for certain is that Sraffa was reading-or far more likely rereading-the Principles in the spring of 1923, when, after the failed attempt to get to England, he probably decided to take up a university career and seek some teaching post for the following academic year of $1923-4,{ }^{4}$ possibly - as Naldi (2004: 95) conjectures-because it seemed to him that this would ensure a relative degree of independence and a chance to escape fascist pressures. Sraffa filled a writing-book with notes in Italian, dated April 1923 [D1/2], which he subsequently revised, without recording the date of his afterthoughts, with a great many pencilled additions and corrections.

The notes do not refer to the entire volume of the Principles, but concentrate intensively on a few passages and chapters. There are no outline descriptions, attempts at summary or abstracts of general principles, as may be jotted down when preparing a lecture. One finds only hairsplitting analyses of details, often concentrating on a note or even a single word. Some of these passages come close to becoming obsessions for Sraffa: again we find them marked, and at times commented on, in the copy of the 
eighth edition of the Principles, which Sraffa used for work ${ }^{5}$; they are listed in the index Sraffa had drawn up on the inside back cover of the volume, and they are recalled countless times over the following years. Let us take one example among many. Section V, xii, 3 of the Principles comes at the end of a description of the differences between economies within the individual firm and the economies of the entire industry. It opens with the statement that 'thus' the history of a single firm cannot be made into the history of the whole industry, leading to the introduction of the Representative Firm as an expedient to connect the individual conditions of the firm with the overall conditions of the industry. This 'thus' fails to convince Sraffa, and indeed he later decided to ignore the Representative Firm as such in the 1925 and 1926 articles, and remained unconvinced subsequently. Over and again we find him remarking that it is a non sequitur, as in a variation on the first comment of 1923: "What Marshall says of the "representative firm" contradicts the previous section and is of no practical value: it is put there for the sake of coming to some conclusion. ${ }^{6}$

Another point that struck Sraffa was the footnote on the same page, in which Marshall criticized Cournot for setting out to construct supply curves for the industry starting from the equilibrium of the individual firms, without realizing that the hypothesis of increasing returns for the single firm is incompatible with a market of perfect competition. This is a point that Sraffa was to return to on various occasions, and which would still be on his mind in 1930. In view of the fact that all the comments are critical, this close scrutiny of details in search of contradictions or obscurities gives the impression of a Sraffa determined to find fault.

At this point the pursuit was not yet yielding impressive results; however, it was not an indiscriminate operation, but concentrated on three precise points of disagreement.

First, there are considerations that we may call matters of realism, aiming to strike at Marshall in his ambition as a faithful interpreter of economic realities. Here it is a question of processes that Sraffa holds to be continuous over time (technological innovation, changes in tastes), and which Marshall, by contrast, with undue simplification supposes to occur una tantum. It is also tempting to interpret these hints as showing how Sraffa began to be suspicious of the method of static analysis in general. Although the evidence is scanty and the argument is not spelled out, Sraffa appears already sceptical about the correctness of introducing dynamic considerations into the framework of partial equilibria. ${ }^{7}$

The second issue is criticism of the justification of interest (or profit) as 'natural' remuneration for a factor of production, a necessary motivation for the holder of the factor to supply a certain amount of it, having weighed up the advantages in terms of gain and the disadvantages in terms of effort. We 


\section{Annalisa Rosselli}

may suppose that Sraffa's dissent at this point was above all on ideological grounds. One of the first items in his personal index of the Principles is: justification of interest, the reward of waiting! Marx!!'. Sraffa attacks the apologetic nature of the theory with sarcastic comments. He defines as 'ridiculous' Marshall's description in the Principles-attempting to make interest appear a matter of instinct - of the mason $(\mathrm{V}$, iv,1) who builds his own house and compares his pleasure in the completed building with the effort made, the latter being valued moreover at a rate of compound interest taking account of the time passing between the production of effort and the dwelling becoming available for use. ${ }^{8}$ And then, the idea that profit is to compensate the capitalist for the risk of failure prompts a sarcastic response:

If we have to take account of those who lose capital in order to calculate profits, then to calculate wages we must also consider the 'wages' of the unemployed, soldiers, workers who die at work, etc. ${ }^{9}$

Nevertheless, the criticism of the Marshallian theory of distribution is not confined to expressions of scorn and deprecation. Sraffa questioned the logical grounds on which Marshall excluded rent from production cost-a matter of 'political' significance, a point we shall return to later. In fact, as we read in a note written in those years, entering into the cost of production was 'the test of social utility of a class', and for the Classical economists indicated what could or could not be taxed without halting development (D1/3.3). Sraffa asked in the 1923 writing book:

Why are profits included in the cost of production while rent is not? Because, says $\mathrm{M}$ [arshall], profit is necessary to induce people to produce capital (through waiting), while land is there ('it is produced') in any case. It may be objected: profit (interest) is necessary for capital to be lent, not produced: rent, too, is necessary for land to be lent ... nor should profit be included in the cost of production: like rent, it becomes a 'surplus'. 10

This is the answer - rent and profit are on the same side, and therefore either both are included in the cost or both are excluded, and belong to the surplus - that Sraffa would give six years later, in his lecture course on Advanced Theory of Value ${ }^{11}$. And, although far more fully developed, Sraffa's line of argument against Marshall would be based on the same assumption: a concept valid in the aggregate-land is fixed for the overall system-cannot be lumped together with motivation, which is a matter for the individual owner of the factor, for whom neither capital nor land are fixed because his ownership is partial. In his lectures Sraffa held that if remuneration of the factor was to induce the individual owner to increase the proportion of property to be used for production, making it unavailable for alternative uses, then there was no difference between 
land and capital. In this case, however, the theory of distribution is no more than a theory of opportunity cost. If, on the other hand, remuneration of the factor was to serve to increase the overall quantity from which to draw saving and favour accumulation, then past profit and past rent were equivalent, since saving could come from both and both were necessary to increase production. In any case, once cost was transformed into loss of utility to allow for the balancing of contrasting motivations, Marshall could not go on treating rent as something different from profits and wages, as this distinction belongs to another theory of costs - that of the Classical economists.

The third aspect we see as a common theme running through a series of remarks made by Sraffa in his notes of 1923 is what we have described as 'quest for the fatal error'. Sraffa was not convinced of the fundamental symmetry of supply and demand, where symmetry implies that demand and supply play the same role in determining prices (and therefore, according to Marshall, both are 'causes' of value), and, at the same time, that both are constructed on the same principle of a balancing out of individual motivations. To explore the asymmetry between demand and supply, Sraffa made an-abortive-attempt to plumb the difference, suggested by Marshall in a note to the Principles, between the 'real life' behaviour of the individual underlying demand (given the price, the consumer chooses the quantity) and supply (the entrepreneur can decide the price, but not the quantity that will be purchased). This was a matter that was to take Sraffa on to further reflections, and a file entitled 'Marshall note p.457' (D1/29) brings together a great many notes-some in English, some in Italian, written in successive periods-expanding this asymmetry of behaviour, representable in a supply curve with infinite elasticity meeting a negatively sloping demand curve. It may well be that these notes constituted the starting point for a planned article, of which we have only the title: 'Causal relations between price, demand and supply'. ${ }^{12}$

Examining the balancing out of individual motivations, Sraffa makes reference to one of the passages from the Principles that was to prompt particular attention and discussion in his subsequent writings-the note (IV, iii, 2) in which Marshall illustrates the principle of marginal productivity, considering a plot of land that is repeatedly ploughed, and into which the farmer channels successive doses of capital and labour until the marginal costs (of production) are balanced by the advantages (the marginal utility of the product). Taking an approach that would prove fruitful in his articles of 1925 and 1926, Sraffa picks out a contradiction in Marshall and his method of partial equilibrium-a contradiction between the calculation of advantages that requires monetary measurement, and therefore the prices of product and factors must be known, and the 


\section{Annalisa Rosselli}

impossibility of isolating this calculation from the more general effects on the economy of a variation in amount of the factors utilized:

This note is a shining example of how the whole argument fails to stand up. [...] how can we say that a hundredweight of potatoes rewards the grower for the expenditure of $£ 1$ if no account is taken of the price of potatoes? How can two different things be compared otherwise than on the common basis of their value (or utility, or price)? [...] Supposing but not granting that such an abstraction from variations in value has no practical importance in the case of a single farmer, in any case it makes the theory inapplicable to agriculture as a whole: an increase of $10 \%$ in the capital and labour employed in agriculture and in the quantity of products would raise the prices of the former and bring sharply down the price of the latter. ${ }^{13}$

\section{The 1925 and 1926 articles and two unresolved questions}

As we well know, the attack on the fundamental Marshallian symmetry of demand and supply finds full expression in Sraffa's 1925 article in the Annali and in the 1926 article in the Economic Journal. These articles have been the object of repeated study from various viewpoints. In the particular case of our interest here-relations between Sraffa and the Marshallian tradition -Sraffa's contribution has been dealt with in the broader context of the state of economic theory of the firm in the 1920s on either side of the Atlantic (Marchionatti 2001) or analysed in terms of the correctness of Sraffa's interpretation of Marshall. In fact the question, as put by Becattini (1986), has been just how correct and well-founded was the identification of the premises in terms of which Sraffa described the Marshallian theory of value in those writings: partial and long-period equilibrium, perfect competition, static analysis. However, embarking on these points would entail going into interpretation of what Marshall really meant, and to what extent he was understood or misunderstood by Sraffa, and this would take us far beyond the space available here. I shall therefore confine my attention to just two aspects of the debate, which remain somewhat obscure, and upon which Sraffa's notes prior to 1928 may cast some light. The two problems are:

1. What meaning are we to attribute to the so-called 'constructive' part of the two articles, or in other words: i) the brief references to the constant returns that must be assumed in the production of commodities, which Sraffa refers to in his 1925 article; ii) the introduction of monopolistic competition into the 1926 article?

2. How are we to account for the exclusion from the publication in English - in the 1926 article or in some other form - of Sraffa's amply 
developed criticism of the very premises of the marginal theory set out in the first part of the 1925 article?

The answer given to the first of these questions in the literature can be summed up as the story of a young Sraffa who knows what he does not want but has yet to know what he wants, and so indicates a number of paths before taking the right path, in 1927, towards a theory that leaves out anything to do with margins, individuals and motivations. This is doubtless a plausible reconstruction provided we are clear about what we mean by 'indicate' since, as the notes of those years incontestably demonstrate, Sraffa himself never tried out these various roads. There is always the possibility that some important material has gone astray, but in all the notes of those years we find not a single page showing Sraffa, for example, reaching out for better definition of the hypothesis that production cost determines price because of constant returns to scale (what technological conditions are taken for reference? What happens for agricultural commodities? and so on) or examining what hypotheses must be made to open out the possibilities of determining price in an industry characterized by monopolistic competition, apart from the banal case of perfectly identical firms examined in 1926. Frankly, such an interpretation, implying a Sraffa who suggests a path to others only to realize immediately afterwards that it is a blind alley and must therefore be abandoned, is hardly credible, even allowing for the impetuous spirits of youth. ${ }^{14}$

It is surely more plausible to conjecture that those parts defined as constructive are no such thing, but rather constitute another form of criticism of Marshall. As has already been pointed out (Signorino 2000, Salanti and Signorino 2001), the destructive part of the 1925 and 1926 articles is based on the strategy of highlighting the poor empirical validity of the Marshallian theory if reconstructed so as to be logically consistent. Sraffa demonstrates that Marshall's supply curve theory, based on costs that vary with the quantity produced, is ultimately compatible only with hypotheses that severely limit its generality, such as that there be significant economies external to the firm but internal to the industry, or that the industry used the totality of one factor. The constructive part of the articles points up the price to be paid in order to reconstruct the Marshallian theory, extending its area of applicability while retaining logical solidity: either one embraces the hypothesis of constant returns, but without going beyond the level of 'preliminary approximation to reality' (Sraffa 1998: 363) (since, as Sraffa would often repeat, costs vary with variations in the quantity produced), or one accepts the existence of myriad 'particular markets', compatible with the internal economies of the firm, but entailing abandonment of the very concept of general price for a commodity. 


\section{Annalisa Rosselli}

Second, by suggesting constant returns, Sraffa criticizes Marshall's neoclassical project of combining the theories of utility with those of cost of production: to be consistent, Marshall must award Ricardo victory over Jevons, since his (i.e. Marshall's) theory cannot stand up without the hypothesis of constant returns. As for Sraffa, the Ricardian price depending on the difficulties of production seems to interest him not for the constant returns it implies, as Marshall claimed, but because it constitutes an example of those real, measurable magnitudes that Sraffa held should underlie economic theory.

In this connection, attesting to the fact that Sraffa was by now reflecting on the foundations of economic theory and the requisites of a theory of prices that might prove more satisfactory than Marshall's, we have a long note (D1/41.3) at present to be found amid a batch of papers containing quotations from Industry and Trade on the elements of monopoly present in competition, and of competition present in monopoly. The note is in Italian, and could have been written immediately before or after the 1926 article. Here Sraffa begins to work on a theme that would find extensive development in his lectures:

The distinction between cost and utility, considered as different, independent and opposite quantities - a distinction at the basis of Marshall's entire system-falls down when the two quantities are considered as 'psychic quantities'. ${ }^{15}$

Sraffa notes that in this respect comparison is possible only if we take cost and utility as equal but of different sign: thus cost is negative utility, or utility is a cost of the opposite sign. Sraffa argues that, having to choose between universalizing cost or universalizing utility, he favours the former alternative. In support of this preference he offers two reasons: 1) the 'eminently bourgeois' type conception of the individual setting out to increase his utility but starting from a basis of wealth, in contrast with the great mass of population in capitalist society that have as their first problem that of not starving to death rather than improving their conditions; 2) the measurement of cost can be replaced by measurement 'of the quantity of "undifferentiated labour" - an abstraction far more acceptable than the "quantity of pleasure",16 (D1/41.4).

If this was how Sraffa saw things, it hardly seems likely that he could have devoted his efforts to corrections or additions to the Marshallian system.

Let us now go on to the second question, which is why Sraffa did not publish the first part of the 1925 article in English. ${ }^{17}$ It is true that by sacrificing that first part the English version published in the Economic Journal proves more efficacious, revolving entirely around the irreconcilability of hypotheses that inevitably arise from admitting the existence of 
increasing and decreasing returns at the same time. However, it is also true that the first part of the 1925 article was closer to Sraffa's heart, in that it contained an explicit attack on the use of marginal variables, and an implicit attack on the theory of distribution based on the principle of decreasing marginal productivity. Let us recall that in the 1925 article Sraffa holds that the decreasing marginal productivity of successive doses of a factor used in a specific production is not a law dictated by technology but, rather, depends on the natural behaviour of the producer who, to maximize the average product, arranges the factors employed in decreasing order of returns.

It was precisely this matter - the use of marginal magnitudes in economic theory in the place of average magnitudes - that Sraffa probably focused on after the 1926 article. There has survived, together with other notes against marginalism (D1/4), the beginning of a paper, carefully drawn up as if intended for publication but left incomplete. The draft bears the title of 'Marginal Shepherd', from Marshall's example (VI, i,7) of the owner of a flock of sheep who has to decide how many shepherds to hire. The example is a sort of 'sheep model' because input and output are measured in physical terms (sheep), and it asserts the principle that the number of shepherds hired depends on the marginal productivity compared with wages. The article opens with polemical force:

The decaying corpse of the honest Shepherd stands so much in the way of any progress in economic theory and it has so much corrupted the atmosphere, that I submit a plea for its removal into that cemetery where he has been preceded by his more illustrious mate Robinson Crusoe.

(D1/4.78)

Here Robinson Crusoe and the poor shepherd are on a par as objects of Sraffa's aversion, the former representing the illusion that economics can treat each individual in isolation from the social context, the latter the illusion that economics can treat distribution as a purely technical matter.

As usual, the 'Marginal Shepherd' seems to have originated from the discovery of a contradiction in a footnote to Marshall's Principles (Marshall 1920: 409 fn.), where Marshall says in the same paragraph that the effects on efficiency of a slight change in the proportions of factors of production 'may be neglected' (i.e. they are negligible) and that it would be 'a grave error' to consider them (i.e. they do not exist at all).

The paper is a new version of the charge that Marshall forced the symmetry between production and consumption by applying to the former laws and principles valid for the latter. Sraffa argues that changes in quantity and changes in proportions have effects belonging to opposite orders of magnitude when regarding consumption and production. In the case of 


\section{Annalisa Rosselli}

consumption, in fact, it is changes in quantity that count and determine decreasing returns, since variations in the proportions between commodities consumed are not considered to have effects on utility of the same order of magnitude and are negligible. However, Sraffa argues, the contrary is true of production, where it is changes in the proportions of factors far from the optimal proportion that determine decreasing returns, while a change in the size of the firm may well go in the direction of greater profitability.

When assessing the variation in production brought about by increased use of a factor (as is the case when seeking the point at which marginal productivity is equal to remuneration of the factor) how are we to know if it is caused by an increase in the quantity of the factor used or by the consequent variation in proportions? Sraffa remarks:

Thus, having assumed that marginal productiveness of one factor is, in respect of small changes, independent of the other factor, he [Marshall] can regard it as 'its own product' of that factor: he is here on the verge of concluding, with Clark etc. that marginal product being 'the product of that factor unaided' it is equal to its proper share in distribution: he refrains from going so far, but still he claims ' that the doctrine throws into clear light the action of one of the causes that govern wages'.

The hypothesis crucial for the argument is that, if we start from an optimum allocation of resources, then the variations in proportions that result from increased use of a single factor have negligible effect. Sraffa set out to show that this was not the case if by optimum allocation is meant the combination that maximizes the average, and not the marginal, product.

It would have been a hefty blow, but the article breaks off, since Sraffa seems unable to decide whether Marshall made marginal or average productivity a function of the proportions of factors.

The Marginal Shepherd reappears in some notes dated December 1927, where Sraffa questions the very foundation of the concept of marginal productivity. Sraffa remarks that if one more shepherd is hired, the number of sheep cannot be kept constant, since at least one must be sacrificed to feed the worker. The ratio sheep:shepherds-which stands for the ratio fixed:circulating capital-is thus affected twice, by changes both in the denominator and in the numerator. Marshall had based his argument on wrong premises, but by then Sraffa seemed less interested in expanding this point and more inclined to conclude that 'the marginal distribution of resources in consumption is just as rotten as that of production and must go to hell with it' (D1/4.62). 


\section{The 1930 symposium}

Sraffa returned to the argumentation set out in the 1925 and 1926 articles in his lecture course on Advanced Theory of Value (D2/4). Detailed comparison between the texts of the lectures and articles would certainly yield some interesting results and possibly reveal significant changes, but the most obvious difference is that in the lectures Sraffa no longer limited himself to pointing out what Marshall would have had to assume to have a non-contradictory theory, but also contextualized his thought in reconstructing the evolution of the concept of cost from Petty to the Austrian school. Sraffa's criticism acquires generality and becomes criticism of Marshall's claim to have completed Ricardo's theory of value, demonstrating the radical difference and irreconcilability between the premises and aims of Marshallian theory and the theory of the Classical economists. In one of the notes he made in preparation of the lectures, kept in a file dated 'End of November 1927' (D3/12/4), Sraffa refers to the 'abysmal gulf of incomprehension' that had opened up between contemporary and Classical economics.

The irreconcilable difference that Sraffa perceives between the Classical economists and Marshall may have originated from a change in his understanding of the Classics more than of Marshall, as Garegnani (2004) suggests. By the summer of 1927, when Sraffa began to prepare the lecture course he was to hold in the following year, the only merit he granted Marshall was that of bringing the attention of economic science back from the realm of metaphysical inquiry into the causes of the value of all commodities, to that of determination of the price of the single commodity (D3/12/3.8). And, a few months later, Marshall is still praised for 'the intelligent application of Leibnitz and Newton analysis to economics' (D3/ 12/11.11). Apart from the correct framing of the problem, however, nothing else of Marshall's theory of price seems to have survived: no real cost as the sum of remunerations inducing utilization of the factors, no 'metaphysics of utility and sacrifice' (ibid.), no utility as foundation of the demand curves (residue of an 'obsolete hedonistic psychology' (D3/12/ $3.61))$. By this stage Sraffa was already prepared to use only empirical demand curves (D3/12/3.69) and 'monetary expenses of production'. As he began work on the equations of Production of Commodities, even thismore nominal than substantial-Marshallian residue vanished. The gulf between Marshall's approach and that of Classical economists (and his own) could not be broader than in their different views of the 'surplus':

Now it is clear that Marshall is not enquiring in the same sort of thing as Ricardo didthe difference between two quantities of 'corn', i.e. of measurable material objects; 


\section{Annalisa Rosselli}

$\mathrm{M}$ [arshall] is enquiring into what the producer thinks is such a surplus. M[arshall]'s surplus therefore does not depend upon the objective magnitude of the things, but upon the 'intentions' of the producer, the 'views' he takes, and the action he 'proposes' to take [...] the two kinds of surpluses belong to different orders of things, to different universes, and are incomparable. The one is suited for the study of the 'motives to do' of producers, the other of the 'ability to do', i.e. to the objective necessity.

(D3/12/9. 86, summer 1928)

Nevertheless, in the quest for logical errors and weak points in Marshall, there was one last episode, although this was probably not on Sraffa's initiative.

We know little about the origin of the Symposium on Increasing Returns and the Representative Firm, which was published in the Economic Journal in March 1930. The title includes the two aspects that the attacks on Marshall had concentrated upon in the previous years: increasing returns-discussed in Sraffa's 1926 article-and the Representative Firm, which Lionel Robbins had judged a useless construction in an article of 1928 (Robbins 1928). Of course, the Marshallian old guard of Cambridge-Pigou, Robertson and Shove-wanted to have their say. Keynes had lined up on the side of the critics: he had, after all, always seen the long period supply curve as one of the 'least complete and satisfactory' parts of the Marshallian construction (Keynes 1972: 207). Keynes had in fact raised many objections to the 1928 article in which Pigou had tried to rescue Marshall from his critics ${ }^{18}$, while he enthusiastically accepted by return of post Robbins's article, writing to him: 'I should like to do away with the representative firm altogether, and I believe that you are right in arguing that it really serves no useful purpose'. ${ }^{19}$ Constrained between his own convictions on the one hand, and pressure from his old colleagues on the other, Keynes might have accepted the articles by Robertson (1930) and Shove (1930) ${ }^{20}$ and called upon Sraffa for an answer.

However things actually went, the Symposium was born as a collection of written contributions, which came under verbal discussion just a few days before publication, on the basis of the proofs, on 24 February 1930, in a thronged meeting of Keynes's Political Economy Club. ${ }^{21}$ The only account we have of how the discussion went we owe to Sraffa himself, who wrote to Einaudi on 18 March 1930:

Dear Professor, [...] you will have seen the Symposium in the Ec.Journal [...] We have also, as it were, played it through at the Pol. Ec. Club here, and discussion went on for four hours: after which, Pigou had to go to a clinic for a week - the doctor says the smoky air in the room was to blame, but we feel a shade guilty. ${ }^{22}$

In the Symposium as published Sraffa's contribution is very succinct and adds nothing substantially new to the points discussed above. In a nutshell, 
we might say that Sraffa continues to argue that Marshall had failed to show why a firm-whether individual, average, equilibrium, representative or whatever-should not step up production if it is subject to increasing returns and the market is one of perfect competition.

So much for the publication; but the answer to Robertson as planned was far broader in scope, as attested by a number of drafts that have survived of a part that was to have preceded the published part, and in which Sraffa had intended to address the subject of the Representative Firm (D3/7). The notes are indeed interesting, and would merit a paper apart. Equally interesting are Sraffa's comments on the contribution by Shove, schematically annotated for discussion at Keynes's Club given that Sraffa probably had not had time to include them in the written contribution. Shove was in fact notorious for his habit of never deciding to take his work to the printer's, or, if he did, taking it back the day after, a prey to agonizing afterthoughts. (Incidentally, note how Sraffa pinned Shove down with a question showing just how aware he was of the difficulties entailed in the analysis of monopolistic competition: what is the sense in talking about the demand curve of the industry if every single firm has its own particular demand curve?)

In the draft of his reply to Robertson (and indirectly to Robbins) Sraffa wondered what the difficulties were that Marshall set out to solve by bringing in the Representative Firm. He returned to the perplexity experienced in his reading of 1923, and to the page of the Principles that had never convinced him with the note on Cournot where Marshall showed he was perfectly well aware that a firm subject to increasing returns tends to dominate the entire market. He was also struck by the question raised by Robbins, who wondered why the theory needed a representative firm if it had no need of a 'representative worker'. While Robbins had concluded that the Representative Firm was in fact useless, Sraffa concluded that its function in Marshall was not to reconcile perfect competition and increasing returns, as he may have supposed, and as Robertson and the others continued to argue in defence of its importance. It is not at the level of theory of value that the Representative Firm plays its role, but in the area of theory of distribution-indeed, it is 'the very foundation' of Marshall's theory of profits. The Representative Firm comes into play when discussion turns to the composition of the supply price (i.e. distribution), and not to the laws of its variation (i.e. value)-two issues that Marshall kept separate, in 'watertight compartments' (D3/7.14). ${ }^{23}$

There must enter into the composition of price something that we call the normal rate of profit, and the Representative Firm - a firm neither too young nor too old, neither too successful nor too unsuccessful-marks its 


\section{Annalisa Rosselli}

level. What, however, is this 'normal rate of profit'? It is not a sum representing the remuneration of the management since, in that case-as Robbins had argued - we would have to conclude that different remunerations were to go to different capacities, just as different wages are given to workers with different degrees of efficiency, and there is no need for the Representative Firm. Nor is it the reward necessary to attract new entrepreneurs into the sector since, as Marshall admits with his theory of 'high prizes' (VI, iii, 6), it is the hope of remuneration beyond, and not within, the normal limits that attracts workers to certain occupations, and entrepreneurs to certain lines of production. In Marshall-Sraffa argues profit is a third element that is added on to the interest on capital and the remuneration of managerial activity, and has to do with the ownership of capital since it must retain some definite relationship with the quantity of capital employed: it is a rate of profit. The Representative Firm serves to determine this third element.

The question is: how can Marshall reconcile a rate of profit that depends on the capital employed, and thus tends to uniformity, with his explanation of the different rates of profit that the non-representative entrepreneurs obtain thanks to their luck and ability? According to Sraffa's reconstruction-and here would seem to lie the new weakness he identifies in Marshall-it is necessary to conjecture that entrepreneurs of different capacities control different quantities of capital in proportion to their abilities. A 'startling enough' conclusion, but the only one allowing for reconciliation - as usual - of the various claims made by Marshall: the need to recognize a difference between capital and labour and to deny it at the same time; to admit that profit depends on the ownership of capital but at the same time celebrate the 'fundamental unity underlying the causes that determine normal profits and normal wages'.

This first part of Sraffa's contribution to the Symposium also remained unfinished. Having examined the relevant passages in Marshall, Sraffa concluded that the proportionality between profit and capital was recognized by Marshall, but with so many 'important and far-reaching' qualifications that we can ultimately only wonder whether the ratio between profit and capital 'has any more meaning than the ratio of the age of the captain to the height of the mast'.

\section{Conclusion}

There are many hypotheses we might advance to explain why, after his contribution to the Symposium, for a long time Sraffa seemed to lose interest in fathoming the contradictions and weakness in Marshall. His attempts will 
be resumed in earnest only after the appearance of Production of Commodities (D3/12/42) but even then they did not lead to any publication.

Among the possible reasons we may doubtless include contingent matters, such as preoccupation with the edition of Ricardo's works, which began precisely in February 1930. A more decisive reason, however, may have been his work on Production of Commodities, which, paving the way for an alternative approach, made it pointless to spend so much energy on specific criticism of Marshall.

There is, however, one more-albeit less weighty-element that we can add. All Sraffa's abandoned endeavours mentioned in this paper concluded not with denial of the logical correctness of the argumentation, but with references to passages in Marshall that seemed to contradict the thesis previously upheld by Sraffa. Like Keynes and many others, Sraffa too ultimately surrendered in the face of the difficulty of pinning Marshall down in facile classifications. In 1930 Sraffa could only admit that Marshall '[...] removes the sharpness of every possible criticism through its having been already "accounted for", (D3/7). And, indeed, he had always been surprised by Marshall's intuition, which saved him from drawing wrong conclusions from shaky premises. The impossibility of constructing a critical case that was not contradicted by other passages in Marshall's work, together with Sraffa's growing awareness that this was not the way to shake the Marshallian faith of his Cambridge colleagues, are probably the causes that led to the end of his 'quest for the fatal error' that had lasted seven years.

\section{Notes}

* My thanks go to Heinz Kurz, Cristina Marcuzzo, Nerio Naldi and the referees of this journal for useful comments and suggestions. I wish to thank Professor Garegnani for granting permission to quote from Sraffa's papers.

1 This is a recurrent expression of Sraffa's. See D2/4/3.120 and D3/7. Sraffa's papers are conserved in the Wren Library of Trinity College, Cambridge. References to them follow the catalogue prepared by Jonathan Smith, archivist. The words or passages that Sraffa underlined have been put in italics. All emphases are in the original.

2 Letter from Sraffa to Charles Parrish Blitch, 6 October 1975. A photocopy of the letter, which is still in the possession of the receiver, was kindly given to me by Nerio Naldi. A draft is among Sraffa's papers (C26/1).

3 A file $(\mathrm{D} 1 / 11)$ brings together notes by Sraffa that could date back to LSE times. The impression we receive from these is that Sraffa was interested in assessing the effects of high wages on labour supply, through considerations on the variations in the disutility of labour and the utility of income. The references to Marshall are few, while there are many to Edgeworth, Jevons, Bernoulli, Pigou, Robertson and Cassel.

4 Marshall's Principles would be the text adopted by Sraffa in his years of teaching at Perugia (Naldi 2001).

5 The copy is conserved in the Wren Library (Sraffa 2591). 


\section{Annalisa Rosselli}

6 "Quello che Marshall dice della "representative firm" è contraddittorio con il paragrafo precedente e non ha alcun valore pratico: è messo lì tanto per concludere'. The translation of the passages from Sraffa's papers is always mine. The original text in Italian is given in the footnotes.

7 This point - that changes that occur over time must be dealt with separately by other parts of economic theory and cannot be confusingly introduced into the problem of price determination-will be raised again in the notes of summer 1927 (see Garegnani 2004) and in the debate with Shove in 1930 (see Rosselli 2005).

8 Sraffa always grew impatient with Marshall when he ascribed characteristics of capitalism to characteristics of the human spirit, for example, when he attributed the increase in saving that distinguished his age from previous ages, to a greater willingness to 'incur present ills for the sake of future benefits' (Marshall 1920: 680), ignoring the fact that, with the introduction of machinery, capitalism had overcome the constraints imposed on production by limited resources and population. Thus, Sraffa observed, far from being a matter of the individual growing more unselfish towards future generations, this happened simply because industrialization had opened up fruitful alternatives to the opulent consumption of the leisured classes of the past.

9 'Se per calcolare i profitti bisogna tener conto di quelli che perdono il capitale, per calcolare i salari bisogna tener conto dei "salari" dei disoccupati, dei soldati, di quelli che muoiono per il lavoro ecc'.

10 'Perché i profitti sono compresi nel costo di produzione e la rendita no? Perché, dice $\mathrm{M}$ [arshall], il profitto è necessario per indurre la gente a produrre capitale (mediante l'attesa), mentre la terra c'è ("è prodotta") in ogni caso. Si obbietta: Il profitto (interesse) è necessario perché il capitale venga prestato, non perché venga prodotto: anche la rendita è necessaria perché la terra venga prestata [...]neppure il profitto deve essere compreso nel costo di produzione: esso diventa, come la rendita, un "surplus".'

11 The course was first held in $1928-9$, but it is possible that the specific pages where the issue is addressed (D2/4/3.61-5), and whose numbering shows they were added, were written in the following year.

12 The title is in Italian: 'Rapporti causali fra prezzo, domanda e offerta'. It is hard to determine whether the project was previous or subsequent to the 1925 article. However, it appears more probable that Sraffa had begun to reflect separately on the subject of symmetry between demand and supply, as attested by these notes, and on the 'empty economic boxes' debate arising over Clapham's 1922 article, as demonstrated by the analysis of the hypotheses giving rise to increasing and decreasing costs contained in D1/51.11. Subsequently he might have decided to combine the two subjects in the 1925 article, where the non-proportionality of the total cost of production to the quantity produced is regarded as the foundation of the Marshallian 'fundamental symmetry' (Sraffa 1998: 325-6).

13 'Questa nota mostra luminosamente come tutto il ragionamento non regga. [...] come è possibile dire che un quintale di patate remunera il coltivatore di una spesa di $£ 1$ se non si considera il prezzo delle patate? Come si possono comparare due cose eterogenee se non sulla base comune del loro valore (o utilità, o prezzo)? [...] Ammesso e non concesso che tale astrazione dalle variazioni di valore non abbia importanza pratica nel caso di un solo farmer, in ogni caso essa rende la teoria inapplicabile all'agricoltura nel suo complesso: un aumento del $10 \%$ nel capitale e lavoro impiegati nell'agricoltura e nella quantità dei prodotti, farebbero salire i prezzi dei primi e diminuire fortemente il prezzo dei secondi.'

14 Mongiovi (1996: 215) defines Sraffa's 'momentary interest in the theory of monopoly' as 'an interpretational puzzle' and interprets it as a 'step backward'. 
15 'La distinzione tra costo e utilità, considerate come quantità diverse indipendenti e contrapposte - distinzione che sta alla base di tutto il sistema di Marshall-non regge quando le due quantità siano considerate come "quantità psichiche".

16 ']...] quantità di lavoro non differenziato - un'astrazione questa che è di gran lunga più accettabile che non la quantità di piacere.'

17 The first part of the 1925 article found ample expression in the Lectures, but never found its way into a publication in English.

18 Keynes wrote to Pigou on 2 January 1928, after reading the first version of the article: 'I should have thought that the representative firm was a conception which wasdeliberately-of too vague a character to support the precise mathematical superstructure.' The letter is conserved in Cambridge, King's College Modern Archive, Keynes papers, EJ/1/3/3.

19 Letter from Keynes to Robbins, 14 March 1928, Keynes Papers, EJ/1/3/25.

20 Shove's article, on which he had been working for over a year, appeared as a comment on Robertson's essay, at Keynes's request (See Rosselli 2005).

21 Keynes wrote to his wife on 24 February 1930: 'Tonight Dennis and Gerald and Piero are going to dispute together at my economics Club and a large company will come to hear them. I shall need all my tea cups and more than all my chairs.' Keynes Papers, PP/45/190/4/207. Keynes asked Sraffa (20 February 1930, Add. ms. a 427/22) to invite Robbins, but we have no evidence that he accepted the invitation.

22 'Caro professore, [...] avrà visto il Symposium nell'Ec. Journal [...] Lo abbiamo anche, dirò così, recitato al Pol. Ec. Club di qui, e si è discusso per quattro ore: dopo di che Pigou è dovuto andare in casa di salute per una settimana-il medico dice che la colpa era dell'aria affumicata della stanza, ma noi abbiamo un certo rimorso.' I thank Nerio Naldi for drawing this letter to my attention. The letter is preserved in the Archives of the Fondazione Einaudi, Torino.

23 When Sraffa wrote his contribution to the Symposium, the impossibility of keeping distribution and theory of value separate had already appeared to him quite evident. In fact, the remuneration of factors depends on the quantity demanded of all the commodities together, which in turn depends on the prices of the single commodities. See the lecture added in 1929 in D2/4/3.122-7.

\section{References}

Becattini, G. (1986). L'interpretazione sraffiana di Marshall. In R. Bellofiore (ed.), Tra Teoria Economica e Grande Cultura Europea: Piero Sraffa. Milano: Franco Angeli.

Faucci, R. (1986). Fra Einaudi e Gramsci: Sraffa e la cultura economica italiana degli anni venti. In R. Bellofiore (ed.), Tra Teoria Economica e Grande Cultura Europea: Piero Sraffa. Milano: Franco Angeli.

Gallegati, M. (1984). Analisi parziale ed economia pura: l'economia politica marshalliana in Italia (1885-1925). Annali della Fondazione Luigi Einaudi, 18: 355-410.

Garegnani, P. (2004). Di una svolta nella posizione teorica e nella interpretazione dei classici in Sraffa nei tardi anni 20. Atti dei Convegni Lincei, n. 200: 159-94.

Harrod, R.F. (1951). The Life of John Maynard Keynes. London: Macmillan.

Keynes, J.M. (1972). Essays in biography. In J.M. Keynes, The Collected Writings. vol. X, D. Moggridge (ed.), London: Macmillan.

Marchionatti, M. (2001). Sraffa and the criticism of Marshall in the 1920s. In T. Cozzi and R. Marchionatti (eds), Piero Sraffa's Political Economy. London and New York: Routledge. 


\section{Annalisa Rosselli}

Marshall, A. (1920). Principles of Economics. 8th edition. London: Macmillan.

Mongiovi, G. (1996). Sraffa's critique of Marshall: a reassessment. Cambridge Journal of Economics, 20: 207-24.

Naldi, N. (2001). Piero Sraffa's early approach to political economy: from gymnasium to the beginning of his academic career. In T. Cozzi and R. Marchionatti (eds), Piero Sraffa's Political Economy. London and New York: Routledge.

_ (2004). Piero Sraffa: emigrazione e attività scientifica fra gli anni Venti e gli anni Quaranta. Atti dei Convegni Lincei, n. 200: 81-121.

Opocher, A. (2003). 'Interrelated prices' and Sraffa's critique of partial equilibrium. European Journal for the History of Economic Thought, 10: 479-96.

Pasinetti, L. (1985). In memoria di Piero Sraffa: economista italiano a Cambridge. Economia Politica, 2: 315-32.

Pigou, A. (1928). The Laws of diminishing and increasing cost. Economic Journal, 38: $188-97$.

Robbins, L. (1928). The Representative Firm. Economic Journal, 38: 387-404. (1971). Autobiography of an Economist. London: Macmillan.

Robertson, D. (1930). The trees in the forest. Economic Journal, 40: 80-9.

Robinson, A. (1990). Cambridge economics in the post-Marshallian period. In R. McWilliams Tullberg (ed.), Alfred Marshall in Retrospect. Aldershot: Elgar.

Rosselli, A. (2005). The defender of the Marshallian tradition. Shove and the correspondence with Kahn, J. Robinson and Sraffa. In M.C. Marcuzzo and A. Rosselli (eds), Economists in Cambridge. A Study Through their Correspondence, 1907-1946. London: Routledge.

Salanti, A. and Signorino, R. (2001). From the 1925-6 articles to the 1960 book: some notes on Sraffa's not so implicit methodology. In T. Cozzi and R. Marchionatti (eds), Piero Sraffa's Political Economy. London and New York: Routledge.

Shove, G. (1930). The representative firm and increasing returns. Economic Journal, 40: $94-116$.

(1942). The place of Marshall's Principles in the Development of Economic Theory. Economic Journal, 52: 294-329.

Signorino, R. (2000). Method and analysis in Piero Sraffa's critique of Marshallian economics. European Journal of the History of Economic Thought, 7: 569-94.

Sraffa, P. (1998) [1925]. On the relations between cost and quantity produced. In L. Pasinetti (ed.), Italian Economic Papers. vol. III: 323-63; English translation by J. Eatwell and A. Roncaglia of Sulle relazioni fra costo e quantità prodotta. Annali di Economia, vol. II: $277-328$.

(1926). The laws of returns under Competitive Conditions. Economic Journal, 36: $535-50$.

(1930). Increasing returns and the Representative Firm. A symposium. A criticism - A rejoinder. Economic Journal, 40: 89-93.

(1960). Production of Commodities by means of Commodities. Cambridge: Cambridge University Press.

\section{Abstract}

The paper retraces some of the stages in Sraffa's thinking about the work of Marshall, by drawing on unpublished material in the Sraffa archive from 1923 to 1930. It argues that Sraffa transformed his dissent - which was 
based on ideological grounds - into a 'quest for the fatal error' to demolish the logical construction of Marshallian theory. Some of his attacks were successful (for example, the critique of the relation between costs and output); other attempts failed (the critique of the 'normal rate of profit' and the critique of the concept of marginal productivity) since Sraffa could not find enough textual evidence to support his position.

\section{Keywords}

Sraffa, Marshall, Cambridge School, Increasing and decreasing returns, Marginalism 